\title{
"Stop flexing your roots, man": reconversion strategies, consecrated heretics and the violence of UK first-wave punk
}

\begin{abstract}
The article assesses how the reshaping of the habitus of UK punk's original working-class and lower middle-class practitioners framed their investment in this heavily mediated popular music culture. A reshaping which facilitated an increased reflexivity in these more socially mobile subjects. This is achieved by drawing on both published testimonies and the author's own empirical research into how former first-wave punks now read their earlier practice. In recognizing first-wave punk's initial status as a heterodox cultural formation, discursively defined by the modernist aesthetic it laid claim to and by the violence attributed to it in media representations, the article examines the degree to which its practitioners challenged orthodoxy in their desire to consecrate a new field of cultural practice, with its attendant forms of capital. By drawing on a Bourdieusian conceptual framework, the article demonstrates how firstwave punk derived its affective energy from working-class cultures and predicated this modernist aesthetic on the symbolic value it selectively extracted from them. In undertaking such an account, the article suggests that the violence of first-wave punk, symbolic and physical in form, was symptomatic of the divergent classed habitus of its practitioners. It concludes by arguing that in this respect, punk's opening up of radical space might be read in a more ambivalent light than has hitherto been the case.
\end{abstract}

\section{KEYWORDS}

Bourdieu

Class

Deleuze and Guattari

Field

Habitus

Punk

Social space

Violence

And then one shouldn't forget all the mismatches between embodied history and reified history, all the people who 'feel out of place' - in the wrong place, the wrong job. These out of place people, déclassé upwards or downwards, are the troublemakers who often make history.

Bourdieu (1993a: 47)

\begin{abstract}
Britain is a class-ridden society, but punk provided an arena where the classes could meet on something like equal terms. In the heat of the moment, it wasn't where you came from, but what you could bring to the table. This of course did not remove the deep and ingrained inequity, but it gave a voice and a face to many writers and musicians to whom that opportunity is often denied.
\end{abstract}

Savage (2010)

\section{INTRODUCTION}

The quotes above, from authors operating in distinct disciplines, converge around a desire to recognize the limited agency of individuals, from across the social class divide, as a driver of progressive social change.

For Pierre Bourdieu, the counter-hegemonic positioning of such 'troublemakers' is necessarily only achieved via proto-consciousness, akin to what Raymond Williams (1977) identified as a 'structure of feeling'. Thus challenges to the hierarchy of social class are dependent upon

\footnotetext{
${ }^{1}$ See John F. Myles (2004) for a useful, but disputable, critique of Bourdieu's appropriation of Husserlian phenomenology. For Myles, Bourdieu 'over-polarizes [Husserl's concept of] doxa [the 'natural attitude' arising from habitus] and reflexivity' (91) and in so doing proffers an account of consciousness which is insufficiently nuanced, therefore risking the charge of determinism and thus under-valuing working-class agency.
} 
dominated groups delegitimizing their domination by dominant groups and recognizing such relations of power as socially constituted. This is because Bourdieu (1977) wants to emphasize the limits to which a subject can render transparent to themselves the workings of their habitus, the set of durable, but not immutable, dispositions formed by, and in turn informing, their practical experience; experience which frames their sense of being-in-theworld and thus their perception of what actions and manoeuvres through social space are plausible. $^{2}$

For Jon Savage, the first wave of UK punk offers an illustration of how popular music formations, as one arena of cultural practice, can, in their embryonic stages, allow for the opening up of new social spaces in which those who 'feel out of place' might acquire the beginnings of a new habitus, a fresh perception of the world, in the process reshaping and being reshaped by their social engagement with others. Punk in this reading is a moment in which the breaking down of oppressive hierarchical structures affords a degree of social mobility, an ambitious escape from boredom, routine and inertia. ${ }^{3}$

\section{CLASS MATTERS: DON'T GIVE ME NO LIP, CHILD}

One anecdotal example to illustrate how the punk era of the mid-seventies did indeed open up new social encounters between subjects is set in the arena of popular music journalism. This is, of course, the arena in which Savage himself, as an Oxbridge graduate and therefore possessor of a very specific educational habitus, established his own career as a writer. ${ }^{4}$

The anecdote belongs to Julie Burchill, well established now as a savvy, media-literate provocateur and successful author but known then as a young working-class woman from the provinces. Burchill responded to an advert placed by the New Musical Express for new staff, with the periodical seeking fresh journalistic talent in the context of its own repositioning in response to accusations of its failure to capture punk's initial energy. In Paul Gorman's (2001: 228) collection of interviews with key participants from the period, Burchill recounts the admonishment of a fellow hack, senior to her and male, who patronizingly instructed her to 'stop flexing your roots, man' during a confrontation.

Burchill's reading of this encounter - that a middle-class colleague resented her status claim to an alleged working-class authenticity - reminds us that symbolic violence lingers; the wound must have stayed with her in order to be recollected. It reminds us too that the reshaping of a subject's habitus, as a consequence of inhabiting and reconfiguring new social spaces, can be understood only in the context of recognizing the differentially experienced relations of power that operate in such spaces. Here, we might recall the important work done

\footnotetext{
${ }^{2}$ As Bridget Fowler (1999) has argued, in her sympathetic reading of Bourdieu's work, it is conceptually useful to think of a plurality of habitus: a classed habitus is distinguishable from a gendered habitus, even though, in this example, both intersect in important ways.

${ }^{3}$ The first half of the seventies should be seen as a continuation, and broadening out, of social and cultural trends that first emerged in the sixties, a decade read by some as a period of considerable social movement across classes. In their self-confessed historically-broad analysis of what defines 'cool' as a marker of difference, Dick Pountain and David Robins, themselves participants in the late sixties British counter-culture, argue that for working-class kids especially, the sixties allowed for upward mobility. The burgeoning counter-culture of the sixties 'provided an escape route for many working-class British kids who otherwise faced a life of tedium in the car plant or the milk-bottling line, as testified by the biographies of rock stars from the Beatles to the Clash' (Pountain and Robins 2000: 92). However, as the Guardian's Polly Toynbee (2008) notes, it has been demonstrated that for all the supposed mobility of the sixties through education, the main fields facilitating such movement were economic and not social or cultural. When commenting on data supplied by the Rowntree Trust, Toynbee observes that, 'the only time there was a burst of people moving from working-class backgrounds to middle-class employment was in the fifties and 60s with a sudden increase in white-collar jobs. Educated or not - most left school with no qualifications - people were sucked upwards by a changed labour market. A third of children from working-class backgrounds joined the home-owning white-collar classes. And then it stopped' (Toynbee 2008).

${ }^{4}$ Savage's self-identification as a gay man during a period in which the struggle for symbolic recognition and legal rights for lesbians and gays had only just become widely known, suggests that his educational habitus cannot be fully comprehended without considering his sexual and gendered habitus. In this sense, as I have noted already, the plurality of habitus that we possess invariably mark us as both 'insiders' and 'outsiders', depending on the social spaces we occupy.
} 
by scholars such as Andy Medhurst (2000) and Simon Charlesworth (2000: viii-xi), both of whom have sought to acknowledge, like Bourdieu himself, the insecurity felt by working-class people finding their way in professions traditionally dominated by those classes in possession of high levels of social, cultural and therefore economic capital. ${ }^{5}$ In the case of these authors, academia, as one such space, potentially liberates the working-class scholar through an engagement with objective theory reflexively informed by practical knowledge, and potentially marginalizes them through the strategies employed by the dominant fractions within it, for whom the pursuit of theory becomes an insular preoccupation in which the objective relations which govern practice are constructed, from an elevated, privileged position of alleged disinterest.

It is to the question of how Bourdieu theorizes social space that I now wish to turn in order to outline the methodological approach I employ in my account. Bourdieu's conceptualization of field theory will allow me to examine how first-wave punk marked the opening up of new social spaces, and how these were inhabited, experienced and reframed by a range of classed subjects. Specifically, I want to consider the moment in the mid-seventies when an initially small group of Bourdieusian 'trouble-makers' challenged the elitist assumptions then underpinning UK rock music by championing a Do It Yourself ethic. Namely, the moment punk emerged in Britain as a popular music formation and helped open up the possibility of new forms of ontology for a generation of youth.

My contention is that such an analysis, informed by a materialist reading of punk, can illuminate our understanding of how social class was made sense of, and utilized, by its earliest producers and consumers. It can also proffer an account of punk's dialogic encounter with the UK establishment, which was, as Stewart Home (1988) reminds us, unnerved by punk's exaggeration of 'media stereotypes of working class belligerence.' I want to consider, then, how these first-wave UK punks contributed to the discursive construction of punk culture in order to reflect their own classed-inflected beliefs and values. In so doing I will question the degree to which class is central to an understanding of the conflicting aesthetic and ideological positions punk adopted.

\section{METHODOLOGY: WRITING ON THE WALL}

The concept of field is one of three central to Bourdieu's theorization of the social world. Bourdieu argues that for its explanatory force to be understood properly, we must conceive of it in relation to his other two central concepts: habitus and capital. Employed malleably, Bourdieu's conceptual triumvirate provides a framework that allows for recognition of the antagonistic social relations governing the formation of selfhood, a way of theorizing power. Thus a subject's embodied sense of being-in-the-world can only be understood in the context of recognizing how their singular body is always situated in the contested fields of social, economic and cultural practice and accordingly reflexively produces, in relation to other bodies, the dispositions which frame life expectations. In producing such propensities, the possibility of acquiring value through the accumulation of capital - both consecrated and emergent in form - is opened up. The singular socialized body best equipped to re-orientate perpetually to new, dynamic fields of practice is likely therefore to secure value through mobility.

For Bourdieu, then, the fields of practice in which we operate are sites of struggle and for this reason alone cannot be theorized as static, functional spaces. This is not to argue that existing field hierarchies can be overturned easily or, one would hope given the power Bourdieu invests in them, dismantled. 'Free play' for Bourdieu is possible but the central field of power sustains its durability due to the authority exercised by its participatory groups, for whom a 'feel for the game' - a second nature awareness of what is and isn't permissible

\footnotetext{
${ }^{5}$ Bourdieu resisted a formal autobiographical account of his life in French academia but as Grenfell and Hardy (2007: 10-14) note, his life's work might be read as an existential response to the forms of domination he experienced throughout his life, both as a working-class student from a peasant background and as a young academic working his way through the formal echelons of French university life.
} 
within the field, and how exclusionary boundaries can be enforced to secure it - is always in evidence. He states,

\begin{abstract}
Constant, permanent relationships of inequality operate inside this space [field of television], which at the same time becomes a space in which various actors struggle for the transformation or preservation of the field. All the individuals in this universe bring to the competition all the (relative) power at their disposal. It is this power that defines their position in the field and, as a result, their strategies.
\end{abstract}

(Bourdieu 1998a: 40-41)

Bourdieu's account of the field of power and the overlapping subfields which connect to it actors, especially ones rich in symbolic capital, inhabit numerous fields - is pertinent to the emergence of punk in Britain because this popular music culture operated across various fields, which it sought to reconvert. Thus it challenged most obviously the field of rock music but it also heretically questioned the legitimacy of the established order in other coterminous fields of cultural production. ${ }^{6}$ Indeed, in the anarchic rhetoric of certain punk groups in the late seventies, such challenges to status were in danger of being insufficiently radical, hence calls for the dismantlement rather than reconversion of hierarchical structures, a radical politics captured in Crass' 'White Punks on Hope' (from Stations of the Crass, Crass Records, 1979).

This idea of dismantlement is useful, too, in assessing the implications of Bourdieu's concept of habitus for a radical politics of subjectivity. In J. Daniel Schubert's (1999) reading of the concept, refracted through the 'schizoanalysis' lens of the utopian philosophy of Deleuze and Guattari, habitus needs to be metaphorically 'exploded' because it retains traces of Oedipal structures, captured in Bourdieu's theorization of symbolic violence. As Schubert argues, 'Bourdieu's concern is with the symbolic violence that results from the ways in which categorisations categorise and order society. Schizophrenia is a way to transgress and explode those categorisations and those orders.' (Schubert 1999: 105/6) Wither the deterritorializing political claims of punk in this regard?

I will examine these strategies of reconversion and dismantling by critically examining published accounts of key punk practitioners in respect of their immersion in punk culture. I also draw on the testimonies of a sample of punk fans, gleaned from a research project on class and gender formations in relation to glam rock, in which an interpretative account of their phenomenological engagement with punk is proffered. ${ }^{7}$ Such testimonies are valuable because although they run the risk of producing un-reflexive mediations of past experiences the unreliability of autobiographical memory - they possess a revelatory value. This is especially so if we view the sociological gaze as an opportunity to establish the existence of what Andrew Abbott identifies as, 'a lyrical impulse in sociological and social scientific writing' (2007: 96). Thus the accounts of my interviewees, and my account of them, can capture emotional truth without the loss of objective rigour. It is with these positions in mind that I now wish to explore how punk emerged and positioned itself within the field of rock music in the mid-seventies.

\footnotetext{
${ }^{6}$ Examples: music production and distribution (Rough Trade); design (the innovative work of people like Malcolm Garrett, Peter Saville and Linder Sterling); music journalism (NME, Sounds and Melody Maker); television (most obviously, the innovative approach adopted by Tony Wilson, as discussed in this article); fashion (McLaren and Vivienne Westwood); club culture (Chris Sullivan, Steve Strange and Rusty Egan); avant-garde cinema (Derek Jarman); writing (John Cooper Clarke).

${ }^{7}$ The first stage of this project, conducted between 2006-2010, generated a substantial archive of research data, from which this article selectively draws. I continue to interview fans of glam in order to expand it. Eschewing what some would regard as the methodological rigour of orthodox correspondence analysis, I employ questionnaires and interviews, in both formal and informal settings, as well as email correspondence, with a number of glam fans whose first real articulation of their sense of 'feeling out of place' was in their immersion in the punk culture of the mid-to-late seventies.
} 


\title{
COMPLETE CONTROL: PUNK'S RECONVERSION OF THE FIELD OF ROCK MUSIC
}

\author{
Bakunin would have loved it. That was Sex Pistols, the leaders in their field. And all three of the \\ bands tonight without recording contracts yet playing music in their own fields a lot better than most \\ bands with recording contracts.
}

Anthony H. Wilson (28 August, 1976)

It takes a certain form of educational capital to name-check a Russian revolutionary when eulogizing a band's television debut. Regardless of his counter-cultural posturing and status as a grammar school-educated Oxbridge graduate, Wilson, Manchester's then über dilettante, was right to detect in the Pistols' performance not just a proto-class politics but also the anarchic sensibility they gave voice to.

A study of the mid-seventies commissioning policy of So It Goes, the youth-oriented programme featuring the Pistols and fronted by Wilson, confirms that the production team behind it was itself in a process of transition, necessarily negotiating the wider societal changes that punk was concerned to acknowledge. Steve Hawes, one of the production team behind the second series, identifies in the Pistols' performance the 'year zero' manifesto that came to define punk discursively. For Hawes, 'putting punk on television' meant that the old certainties and privileges of the past were threatened with de-legitimization. In his own field, the complacent self-confidence of a university-educated elite working in broadcasting, assured of its authority to judge and in its expression of 'good taste' - necessarily reflexive enough to acknowledge new trends as long as they reinforced hierarchies of taste - could not be sustained: '[Punk] was not something prefabricated to be relayed by television but rather something to engage with, something open-ended: not just a sound, but mood, drive, clarity of attitude, an unspoken sense of class war being waged through a new cultural formation.' (Hawes 1999: 55/56)

Hawes's summary of punk, as an energy force informed by barely articulated class divisions, has been enshrined in the countless liner notes accompanying the ceaseless commercial reissues celebrating its middlebrow artifacts, whether seminal records, artworks or fashion collections. It is perfectly respectable in the contemporary moment for punk's original movers and shakers, now in their late fifties and therefore statistically likely to be at the summit of their career trajectories, to gain economic capital from their re-affirmation of this orthodox reading of punk, often espoused at exhibition events at increasingly prestigious gallery spaces. ${ }^{8}$ Nonetheless such attitudinizing is valid to some degree: the field of rock music as it was defined in 1975 was predicated on elitist - and therefore classed - assumptions concerning its artistic authenticity and claims to canonical status; anxiety claims informed by its recent spatial occupation of popular culture. Rock music, emergent in form in the late sixties, was aspiring to dominant status. As Hawes notes, the list of band names presented by the production team of the second So It Goes series to Wilson in response to his request for interesting performers, and rejected by him, was predicated on this canonization of artistic 'leaders': 'For those with a set of musical values, learned in the sixth form and affirmed at university, which aped the high-culture values of good taste, individual expressivity and trained musical virtuosity, the prospect was the replacement of something [symbolically encoded with value] with what sounded like nothing [punk's heterodox energy].' (Hawes 1999: $56)$.

In the connected subfield of rock music journalism, as noted above, similar tensions around value and status were played out during the mid-seventies. The first-hand journalistic accounts of the period preceding punk, captured by Paul Gorman (2001), paint a complex

\footnotetext{
${ }^{8}$ Examples include: Panic Attack! Art in the Punk Years, 5 June 2007 - 9 September 2007, Art Gallery, Barbican Centre, London (http://www.barbican.org.uk/artgallery/event-detail.asp?ID=4998), Punk: Chaos to Couture, 5 May 2013 - 14 August 2013, Metropolitan Museum of Art, New York (http://www.metmuseum.org/exhibitions/listings/2013/PUNK) and the permanent collection of punk memorabilia housed at the $V$ and $A$ (http://collections.vam.ac.uk/style/punk/643).
} 
picture of a field in the process of reconversion, again informed by social class: the recollections of key writers from the period, employed by publishers of the NME, Melody Maker and Sounds - papers which were themselves challenging the stylistic and design conventions of the wider print media field - are revealing because they suggest that the distinctions between old (sincere middle-class rock) and new (parodic working-class punk) were being muddied already. Thus whilst these accounts inevitably contribute to the canonization of each journalist - primarily those with career histories rooted in the sixties alternative press - more reflexively there is acknowledgement, too of their relatively privileged status and how, with the onslaught of punk, this was being challenged in respect of class and, importantly, gender, as we have seen with the arrival of journalists such as Burchill. Challenged, too in terms of processes of distinction making: as lan Macdonald notes, he and select other journalists, 'felt like pioneers, in a sense, pioneers of the first era of postmodernism in pop music... when the music started to be conscious of itself and look back and begin to make syntheses and style references and be ironic.' For Macdonald, such ironic distancing allowed for journalistic playfulness, which ensured that, at least in part, 'The music scene lost a lot of its solemnity' (Macdonald quoted in Gorman 2001: 190). But if, as I am arguing, claims for the valorization of the rock music canon were always contested, the testimonies Gorman extracts from journalists such as Neil Spencer do reinforce the perception that non-white, non-rock music - reggae and the beginnings of disco - was largely ignored during this period (Gorman 2001: 189). I would propose this is because these racialized genres had yet to, like punk, gain sufficient currency, required in order to accumulate capital, an argument I will go on to develop.

We can read punk, then, not just as a moment in which class-based antagonisms were rendered visible externally (in opposition to a conservative establishment) but also internally in respect of the conflicting class-politics of punks themselves. I have argued elsewhere that such antagonisms had been played out less visibly in the glam rock formation of the early seventies, an under-acknowledged antecedent of punk. These antagonisms are evidenced most obviously in the appeal of Bowie and Roxy Music, exemplars of Macdonald's selfconscious post-modern pop. Glam was a formation in which a fraction of the male working class expressed its social mobility in the aesthetic divisions it mapped on to the music formation's divergent factions; factions framed by the educational capital its members accrued (Branch, 2012). ${ }^{9}$ I want to argue that such divisions were central to punk, although also rendered problematic by it. The politics of class located in punk was primarily about the construction of a division between a working-class sensibility of energy and vitality, in opposition to a middle-class sensibility invested in status through the appropriation of symbolic value. But it was also about the divisions within these class formations, most keenly felt by those 'out of place' and therefore occupying peripheral spaces; borders to be either traversed or policed by those in closest proximity to them.

Dick Hebdige (1979) identified this division in his valorization of art-school educated punks as cultural innovators, nevertheless indebted to an unacknowledged appropriation of, and 'phantom' dialogue with, non-white cultures. Jon Savage replicates a similar division in his definition of the second wave of punk ('77-'78) as the point at which, 'the Punk diaspora starts...this occurs through the split between the arties and the social realists.' (Savage 1991: 583). These accounts are developed by Philip Kiszely (2013), whose nuanced empirical investigation into how particular venues facilitated the formation of punk subcultural scenes, captures how such divisions operated spatially: in Manchester's Pips, the Roxy Room section of the club spatially partitioned 'alternative punks' - feminized through their educational capital in accordance with my own empirically-derived research regarding fans of glam rock - from 'Perry Boys', inhabitants of the main club space. The latter are implicitly class-coded in the labels ascribed to them: straight and violent 'punters'. Here, subcultural affinities serve as a way of distancing classes. As one of Kiszely's interviewees states,

Going to the toilet in Pips was always nerve-racking because you'd have to leave the safety of the Roxy Room and head for the main part of the club. And you'd get hassled coming out at the end of

\footnotetext{
${ }^{9}$ Art-school glam (Bowie, Roxy) in opposition to rock-n-roll glam (the Sweet, Mud).
} 
the night, too - as you met everybody else from the other rooms. The Bee Gees, as we used to call them - you know, the straight kids.

In Peter York's (1980) account of the same period, although problematically London-centric in its impressionistic case studies, these class divisions explain the romanticized yearning for an (already lost) authentic working-class identity by a newly emergent middle class York labels, 'Thems' in acknowledgment of Richard Hoggart's use of the term. 'Thems', 'are predominantly suburban middle-class...By instinct, of course, they are elitist - though they would not see it that way, or be sure what the word really meant.' (1980: 119) For York, such social aspirants represented a 'new sensibility, self-conscious, equivocal, eclectic, post-modern' and their emergence tells us much about the shifts in culture and society during the period in which punk emerged (1980: 128). Thus the very idea of a stable, 'real' working class was, York argues, an illusion that punk perpetuated,

\begin{abstract}
...the punk idea of working-class authenticity, in a time of social mobility when the 'middle class' was expanding and changing before your eyes, was a period fantasy, a narrow focus. The reality was that 'working-class' and 'lower-middle class' were so confused - basically a matter of generations - you could play it any way you wanted. In Croydon or Ilford the taxi-driver's daughter works in Barclay's and the plumber's son lectures in computer technology at a Poly. And highrise alienation is pretty remote to kids from there, since nothing can convey adequately the sheer pleasantness of their kind of background. It produces kids who've had things nice pretty much from birth - it was their parents who'd been through it before they'd got the mortgage and left Kilburn or Camden Town. This sort of suburbia produced the original mods...
\end{abstract}

(York 1980: 206)

In other words, a complex mix of aspiration and nostalgia by virtue of their class trajectory motivated London-based first-wave punks.

For Savage, the division he attributes to punk was cemented by the reactionary policies of a perennially out-of-touch music industry, which appeared intent on commercially exploiting it at the expense of nurturing its radical potential, which was already being recuperated as early as autumn 1977,

The music industry had long got involved and turned it all into dreadful 30-year-old pub rockers with bleached hair or, even worse, the endless refried mod of The Jam. For all of us in varying degrees, the thing we'd loved about groups like Subway Sect, the Banshees and The Slits was that they were new. Punk had become a cliché, and we wanted to continue that sense of newness, of discovery...

(Savage quoted in Gorman 2001: 251)

I agree with Savage's insistence on punk's heresy being located in its 'newness'. However, the division he identifies tells us much about how aesthetic value is differentially attributed by tastemakers such as himself; about those in positions of relative power within a particular field and therefore able to shape how it is discursively constructed. Savage's distaste for the suburban working-class populism of The Jam is an aesthetic judgement, which reveals as much about the classifier as what is being classified (Bourdieu 1984: 6). Thus the question remains, on what normative foundations might we rest such a judgement? For Bourdieu (1993b:188), sociological deconstructions of particular fields of cultural production are useful because they challenge the 'belief in the miraculous virtues of pure interest in pure form' by laying bare the manoeuvres of field participants and in doing so reveal their motivations, unconscious or otherwise; motivations which provide an insight into how unequal social relations are fostered, preserved or indeed challenged.

If we view the emergence of punk as an energizing force, which sought to reconvert the field of rock music - and the tangential fields of art, design, literature, film and fashion - we need to acknowledge that the energy Savage detected in it was derived in part from the shift in habitus of a class on the move, necessarily constituted at the borders of the traditional working class and an expanding middle class, the latter marked by its enhanced capital. In this reading the reconversion strategies of first-wave punks remains a necessarily ambivalent one. In the next section I want to consider how punk's heretical innovators - occupiers of the fields de-territorialized by punk - made sense of their newfound status. 


\section{NEW UNIFORM}

'Looking back on those days, nothing can really capture quite how out on a limb the primary people were'

(Siouxsie Sioux quoted in Bracewell 2005)

In Nick Crossley's (2008) detailed spatial account of the birth of the UK punk scene, first in London then in Manchester, a quantitative network analysis methodology is deployed to examine the connections between field participants as I define them. Crossley is interested in how associations, friendships and relationships (working and romantic) between the 'primary people' in punk, allowed it to emerge as a concrete cultural formation. In drawing his data from the published testimonies of such individuals, Crossley maps the connections made by them in order to demonstrate that these were vital to ensuring access to the field of rock music and related subfields: being 'in the know' opened doors. Crossley acknowledges the importance of social capital in relation to the emergence and operation of networks but is less concerned, as my thesis is, with an examination of the extent to which social class informs the acquisition of such capital in its legitimated form and thus helps shape network formation.

Thinking about social class is essential because the autobiographies and authoritative biographies of first-wave punk musicians, and the testimonies of first-wave punk fans, are too suggestive of the profound ways in which this classificatory classification shapes motivation and aspiration. Exploring its effects also allows us to understand why those network participants already socially mobile imbued it with a value to be extracted in order to achieve economic success. Here it is worth recalling Bernard Rhodes' claim that, 'you need the mix of working-class roughage with middle-class kids to make a group work' and as Savage's exhaustive account reveals, the original Pistols provided that 'roughage' in abundance (Rhodes cited in Savage 1991: 71). They were fixed as authentic working-class boys, which is why, Savage suggests, they so appealed to the middle-class, art school-educated McLaren. They validated his romanticized reading of working-class cultures as inherently resistant and non-conforming, a reading illustrated in the text written by McLaren to accompany the promotional flyer for the Pistols' 1977 Christmas Day gig, which characterizes the group's members as Dickensian urchins, bent on anarchic destruction. ${ }^{10}$

The most obvious way in which McLaren coded the class status of the individual Pistols was in his recognition of the lack of legitimate capital they possessed, particularly so in the case of Jones and Cook, whose lack of educational attainment and spatial immobility as young men is more typically representative of their class habitus, which makes their ultimate economic mobility all the more exceptional and fortuitous (Savage 1991: 72-73). Lydon, Ritchie and Matlock, on the other hand, all attended educational establishments beyond the age of sixteen, with the latter studying at Central Saint Martins College. Taking into account exceptions such as Jones and Cook, then, the majority of first-wave punks were upwardly mobile to some degree and in this sense we cannot eradicate social class as a determinant in the acquisition of the modernist aesthetic adopted by them, whereby convention and normalcy were denounced and fluidity and flux privileged. ${ }^{11}$ Thus my interest in the networks Crossley identifies is in terms of the aesthetic sensibility network members shared and what this may tell us about their classed habitus and motivations for reconverting the field of rock music in the context of the framing of punk as a violent cultural formation.

\section{WHITE RIOT}

Unquestionably, the dominant discourse framing mainstream media representation of punk in its first UK phase was the perceived violence associated with it, primarily physical but also

\footnotetext{
${ }^{10}$ Tellingly, McLaren signs off the text as 'Oliver Twist' - that orphan born of 'gentle birth' - destined to guide and patronize the 'ruggamuffin' pistols. See illustration in Stolper and Wilson (2004: 38-39).

${ }_{11}^{A}$ A comprehensive correspondence analysis study is required to map the educational attainment of first generation punk musicians - a task beyond the confines of this article. Nevertheless, a sufficient number of biographical accounts publicly available confirm the claim that punks' early pioneers were recipients of an education unrepresentative of most working-class people's experiences.
} 
symbolic in respect of the profane culture it appeared to embrace. This is evidenced in the numerous tabloid headlines and concerned punk-focused broadcast documentaries set on providing pop-psychological explanations for the alleged nihilism of punks. ${ }^{12}$ What is of interest to me in these representations is the way in which physical violence becomes a way of coding social class, especially what is held up to be reactionary male working-class culture. Bourdieu's self-reflexive discussion of male violence is helpful in this regard. The self-identity of men, framed by the durable social classification of masculinity as dominant, perpetuates a form of self-inflicted violence whereby men are 'dominated by their domination' (Marx quoted in Bourdieu 1998b: 69). In other words, we cannot view the actualization of male violence, nor make sense of its implied threat, without first understanding the patriarchal social relations which, at least in part, produce it. It is with this understanding in mind that we might be able to make full sense of Chris Sullivan's sardonic account of punk's demise,

\begin{abstract}
The whole punk thing had slowly descended into an abyss, one that was, in part, frequented by really horrible, stupid, bland people, those who'd read all the adverse tabloid publicity and actually believed it. Now they were 'behaving as punks' - conforming to the Sun newspaper's scathing viewpoint...they were uncouth and belligerent, they were uncultured and, most unforgivably, they were very dull. For many, it was the ideal excuse for the yob to be in vogue. Now their basic lack of education and supreme ignorance could be a help rather than a hindrance. Their total lack of manners and personal hygiene could go unnoticed.
\end{abstract}

(Sullivan quoted in Colegrave and Sullivan 2001: 312)

In short, the uncouth and uneducated 'yob' - the classed categorization that the Sex Pistols relied upon as a way of authenticating their outsider status - was to blame for the death of firstwave punk, which was, unlike him, creative, interesting and intelligent. It is how class is coded in this respect that I want to bear in mind when evaluating the testimonies of the fans I interviewed. Let me make one final point in advance of this evaluation: Bourdieu stresses in his conception of the relationship between habitus and field the importance of the temporal disconnect between the transformative opportunities available as a consequence of field changes and the speed with which agents might grasp such opportunities. The length of temporal delay is, according to Bourdieu, largely dependent on an agent's habitus and the capitals they possess. He notes that, 'In a general manner, it is people who are richest in economic capital, cultural capital and social capital who are the first to head for new positions.' (Bourdieu 1996: 262). Thus 'The hysteresis of habitus... is doubtless one of the foundations of the structural lag between opportunities and dispositions to grasp them which is the cause of missed opportunities and, in particular, of the frequently observed incapacity to think historical crises in categories of perception and thought other than those of the past.' (Bourdieu 1977: 83).

Understood in relation to punk, we might propose that to comprehend the motivations of its earliest participants, and their readiness for the heretical role punk would provide for them, we need to account, therefore, for their earlier cultural practice. Recognition of the period of time required for influences to be absorbed and rearticulated is crucial, which is why many of the testimonies and comments in this section refer to the period 1974-1976, a period as I noted above, dominated by 'serious' rock but under threat from the yet-to-be consecrated music formations of glam rock and soul.

\title{
OLD HABITS, NEW HABITS ${ }^{13}$
}

Habitus is a type of machine to pose values without having the need to pose the question of the value of what is posed as value

(Bourdieu 1988: 37)

Value is at the core of Bourdieu's thinking in respect of how agents move through social space and police boundaries within it. Social space familiar to us in field form provides opportunities

\footnotetext{
${ }^{12}$ Brass Tacks, BBC, 1978.

${ }^{13}$ Four of my interviewees in this section requested anonymity and have therefore been referenced by first names only.
} 
to assert the interest that we generate as a consequence of our classed dispositions, without requiring us to reflect on the universal status value of those interests. We desire status because it provides us with recognition, even if such recognition is field-specific and not transferable to social space we are unfamiliar with.

One reading the following testimonies of first-wave punks invites, is to detect a need for them to be marked as purveyors of a self-defined radical aesthetic, in order that they might extract value from it. This is a form of symbolic violence as it is predicated on fixing the Other, marked as inferior. First-wave punks not only positioned themselves against a moribund establishment but also against a fraction of the working-class they fixed disdainfully as reactionary and immobile,

"You know all these horrible ordinary people you've got walking round, they just follow each other in fashions."

Unnamed punk (1977)

"...safety pins that out-of-towners, sort of country bumpkin type people, have really latched on to"

Jordan, first-wave punk (1978)

Both these quotes point to the need for punk originators to distance themselves from a constructed mainstream, defined by its sartorial and attitudinal uniformity and conservative impulses. Such counter-prevailing impulses were in evidence when my interviewees spoke of their immersion in punk culture and how it allowed for the realization of desire incubated during the years leading up to punk, as one of them, Jeff Ellis, contends,

It wasn't punk at first... we came to know we were punks. It was more post-glam...working-class glam. We were all kind of Bowie, Marc Bolan kind of fans... We was alienated. That was part of it...to be alienated... The first six months was really about self-expression...creating your own look.

(Ellis 2013)

Jeff echoes the views of a number of my interviewees by referencing the era preceding punk as the moment when his display of difference was first incubated. For Jeff, the allure of glam stars such as Bowie and Roxy Music laid in their celebration of difference, of a dandified outsider status. Malcolm McLaren recognized this affiliation in the disillusioned proto-punks who visited his 430 King's Road base, youth who were,

\begin{abstract}
...disenchanted Bowie and Roxy Music freaks, disenchanted because they didn't get to see those people often any more - those acts had got too big - and now they only heard those tracks in discotheques. It had all got a bit too anonymous for people who really wanted to look individual that's why they'd come to my shop in the first place.
\end{abstract}

(McLaren quoted in Strongman: 2007: 90)

The attraction of glam and later punk for my interviewees was the phantasmal space they opened up, which allowed for the oppressive restrictions of class, gender and race to be lifted, and 'individuality', a socially constructed concept predicated on distinction-making, to be valorized in their absence. Moreover, punk, if only in its first-wave phase, allowed for this quest for individuality to flourish in spaces where the idea of hierarchical elites was challenged, at least rhetorically. As McLaren notes, this was a hierarchical structure proto-punks associated with a rock music establishment increasingly beyond their grasp.

This desire for difference was rendered manifest in the sartorial choices enacted by my interviewees. Initially subtle, and then more visible signs were taken up to connote outsider status, as these interviewees attest,

I've always looked for something different... [punk was] about being different without having to be tough. I had a little triangle of red hair ...that was seen as radical... We were getting our inspiration from youth clubs [the Hartley Centre $]^{14}$, where we all hung out...The first six months [of punk] was

\footnotetext{
${ }^{14}$ The Centre still exists and serves as a reminder of the importance of the need for youth to find a spatial home. See: http://www.renewalprogramme.org.uk/the-hartley-centre.html
} 
really about self-expression... creating your own look...It was only after the Grundy thing that people thought, "oh you gotta look like Johnny Rotten".

(Ellis, 2013)

I first got into Bowie in 73, aged sixteen. And I certainly wasn't going to parade around Nottingham city centre with a thunderbolt across my face then...I didn't really concern myself with the clothes aspect until a few years later, when punk took off. It was only then that I really felt a bit braver and more confident, which I suppose comes with age. I used to wear a lot of second hand retro stuff combined with homemade t-shirts. I put a lot of effort in. Wore a bit of eyeliner. But you still had to be careful. Had to stay in the right pubs to avoid a kicking from the straights.

(Chris, 2006)

These accounts are important to register because they not only reiterate the significance of locating spaces in which to articulate counter-hegemonic practices but also hint at how the allure of difference is so tied up with questions of social class and the quest for distinction: individuality is expressed in the selective use of signifiers in order to represent a more refined, modern sensibility. The quest for distinction was also realized in the music preferences of proto-punks. If the more self-consciously esoteric end of glam remained appealing to my interviewees, other genres of music held equal attraction, particularly if their appeal rested on their marginalized status, as Jeff notes,

\begin{abstract}
In that last year or so of school there was a lot of experimentation; trying to find yourself and different things...[I] went from being rockabilly to glam to dub and reggae and experiment with all different things... Casuals, yes...the casuals were really what came after the mods...they were hooligans... [they] went for very white disco. Black mates at school weren't really into disco, they were into funk...then reggae and then dub...I listened to brass construction, funkadelic ....similar to what Bowie was getting into, really.
\end{abstract}

(Ellis, 2013)

For Jeff, the attraction of punk, but also reggae, was that it allowed for spatial distancing from the social groups that didn't share the same aspirations to escape the confines of class, an aspiration that, as we have seen, was shared by other Bourdieusian troublemakers.

This fluidity of genre preferences, with boundaries continually de-territorialized and reterritorialized - the one constant being the exclusion of the fetishized working-class (mostly male) 'straights' - is captured in Isaac Julian's queer reading of the punk era. In his filmic account of the period, Young Soul Rebels (1991) first-wave punks, coded as progressive, are seen to be taking up the pleasures of sensuous dance music on the non-heteronormative dance floor, a move achieved only after overcoming their snobbish hostility. Elsewhere in the film, skinheads - represented in the film as one-dimensional and reactionary (men dominated by their own domination) - assert themselves in violent opposition, an encounter once again laden with the aesthetic symbolism of inter(and intra)-class conflict. The complex dialogue between soul and punk is evinced further in the following quotes from an interview with the UK dance group Leftfield's Neil Barnes and Paul Daley, where commentary is proffered on the allure of punk,

\begin{abstract}
Everyone in my class was totally into music...Everyone brought their records into school and we'd sit in the sixth form common room playing music all day... To be honest, there were very few punk records I really liked...It was more the attitude I was into. Seeing John [Lydon] on television with Bill Grundy... a young guy tearing into this old guy on TV, calling him a cheesy old cunt. Going to early Siouxsie and the Banshees gigs, where it was total free experimentation. People couldn't play their instruments, but they were making great sounds, so it didn't matter.
\end{abstract}

(Neil 1995)

Punk was aimed at mine and Neil's generation...It belonged to us...[In Margate] There were punk venues next door to soul clubs. It got me into music at an early age: when everyone was listening to the Top 40, I was going out, listening to Lonnie Liston Smith and coming home listening to The Clash.

(Paul 1995)

The reference to social space is interesting here, with a particular educational site (sixth form) from which working-class youth has been historically marginalized, registered as a sanctum. Leisure space, too, was central to the emergence of punk as a new subfield, as Daley notes in his reference to the incubatory role played by particular clubs and venues. Indeed, these 
proto-punk spaces seemed to be valued less because of their rigid adherence to any one music genre and more because of their function in facilitating the emergence of scenes; who was there rather than what was played. In this regard, Jeff's recollection of The Lacey Lady, frequented by John Lydon and John Warden, is revealing,

The Lacey Lady was...it was more soul nights...I found it a bit intimidating but it was quite wild...everyone dressed up [in 1977]...A bit [of an] older [crowd]...I never made friends there. It was soul...there were some there [punks]....

The insider status associated with The Lacey Lady, and with Canvey Island's The Goldmine, is acknowledged in the recollections of Mark Powell, fashion designer,

\begin{abstract}
I remember all the soul boys at the Lacy Lady in Ilford used to wear those see-through Sex T-shirts, the red trousers with plastic pockets, and plastic sandals. On a Friday you'd sometimes see John Lydon, as well as a few other trendy types, in the club. You'd get all sorts...men in demob suits they'd bought...when the Swing revival was going on at Canvey Island. Even Chris Hill (the original disco DJ) did a punk night on a Monday - not a lot of people know that.
\end{abstract}

(Powell quoted in Colegrave and Sullivan 2001:139)

These club spaces warrant attention because their occupants shared a modernist aesthetic predicated on a restless, ceaselessly re-imagined self-identity, rather than on a sharing of tastes in music. As Simon observes,

\begin{abstract}
I loved going to the Lacy Lady...a home from home...clubs like that...the music was okay...but the important thing, the relevant bit, was that you felt really cut free from what everyone else was doing...that was the exciting bit...cut free from all the boring office and shop workers...that was punk. That idea of, you know, I'm with people who look cool, know what's in...are going places, who know where it's at...who share a way of looking at the world, of understanding how to work it and not afraid to be whomever they want...
\end{abstract}

The aesthetic disposition informing Simon's practice allowed him to extract, for deferred exchange, symbolic value in the form of subcultural knowledge. Clubs like The Lacey Lady made Simon feel 'at home' because they allowed him to assert his increasingly legitimized cultural capital spatially, which is why those without such requisite capital felt excluded or intimidated, such as Jeff (see above). Thus we can see that spaces such as The Lacey Lady, or Pips, or the Music Machine in Camden - referenced by Jeff as another desirable location were both sanctuaries from the (often literal) violence of a patriarchal external world read as conservative and reactionary and incubators of a form of symbolic violence directed at social groups devoid of the insider knowledge of socially-aspirant first-wave punks; groups largely defined by their working-class status. The ambivalent politics of such spaces, in which boundaries are simultaneously dismantled and erected, is captured in the following two interviewee' quotes,

I never consciously thought about this at the time but looking back...gigs at places like the Music Machine or the Roxy...going to later clubs inspired by punk, like the Blitz, were as much about me wanting to express my superiority [laughs] as they were about me wanting to seek refuge from people who...couldn't tolerate me being different in any form, straight people who just hate anyone who doesn't conform.

$\operatorname{Tim}(2012)$

I loved going to punk gigs...they were so exhilarating...opened up possibilities for the future...a place [punk clubs and venues] to forget for a moment about being physically and psychologically bullied by dead-end people for being different. 


\section{CONCLUSION: THE KIDS WERE JUST CRASS}

'We really did blow away that upper-class/working-class divide and we were just two guys doing it'.

(Steve Ignorant quoted in Felix and Wolting 2011) ${ }^{15}$

'Crass: 1 gross; vulgar. 2 colossally stupid. 3 utterly tactless or insensitive.

Chambers Dictionary

To what extent is Steve Ignorant's quote illustrative of punk's wider political legacy in its echo of Jon Savage's claim for its egalitarian impulse? The testimonies of my interviewees, and the accounts of the key practitioners that I have referenced in this article, suggest that Ignorant's and Savage's claims over-value punk's transformative power. Yes, it was 'life-changing' for many, most especially when, in the 'heat of the moment' to borrow Savage's phrase, it gave rise to new social spaces such as those inhabited by my interviewee, Jeff Ellis. However, my research indicates that those for whom mobility remained paramount - as an expression of their classed habitus - were those who most successfully realized such transformation and in so doing reinforced existing class divisions. In this sense punk did not break-down class barriers if we take as our starting point Bourdieu's definition of 'class' as a way of theoretically categorizing the dispositions of people who share similar material and social conditions, and tend to inhabit similar fields of practice, but who nevertheless collectively fail to identify as a hierarchically positioned group (Bourdieu, 1991). Class stratification here is understood thus as multi-dimensional and linked to status.

Such consideration is required if we are to make sense of how punk opened up new social space and closed it down; how it subverted the field of rock music by drawing inspiration from a working-class functional aesthetic premised on anti-pretension, only then to replace this field with an equally impenetrable one, fixated on status and the consecration of formerly heretical voices. How, too, first-wave punks like Chris, Simon, Tim and Jonathan relied upon an investment in symbolic capital as a means by which they could distance themselves from what they constructed as a physically violent (masculine) straight world.

First-wave punk's energy was contagious and therefore unnerved established hierarchies. Its nihilistic rhetoric of perpetual chaos allowed for perpetual desire, for the possibility of 'free play' by mobile subjects in fear of what bell hooks has labelled the 'terrorising force of the status quo', a fear of the deadening effects of normalcy and fixity, hence the importance of punk's exhilaratingly experienced seditiousness for interviewees such as Tim and Jonathan (hooks 1992: 22). ${ }^{16}$ In this sense, punk's disruption of established fields of cultural practice allowed for a greater degree of self-reflexivity by those agents drawn to it. However, the socialized, ingrained aspirations of such agents inhibited the destabilization of habitus, the possibility I allowed for at the outset of this article: the reflexive embrace of the energizing intensities of punk culture did not impede an appetite for acquiring symbolic capital because such cultural practice was always experienced in the context of a specific set of durable social relations. To borrow the metaphor used by Deleuze and Guattari (1987), punk's non-hierachical rhizomatic impulses very quickly mutated into 'arborescent pseudomultiplicities' in which the tyrannical authority of the desire for recognition mobilized re-territorializing flows, a desire always predicated upon the fixing of an inferior Other by heretics who sought consecration: ergo the dismissive positioning of second-wave punks as reactionary by Chris Sullivan, Jordan et al. Thus an authentic openness to the Other was forestalled in favour of an intentionality predicated on control and power, concepts valorized in a society which, to borrow again from Deleuze and Guattari, could not 'tolerate a position of real desire without its structures of exploitation, servitude, and hierarchy being compromised.' (2003: 116) In acknowledging firstwave punk's modernist aesthetic, therefore, - defined by its valorization of fluidity and flux over static uniformity - we need to recognize that the adoption of such an aesthetic always runs the

\footnotetext{
${ }^{15}$ Ignorant reflecting, if not necessarily reflexively, on his own class trajectory vis-à-vis his relationship with Penny Rimbaud and the formation of Crass, the anarchist-punk group they co-founded.

${ }^{16}$ For hooks, such terror explains the historical fetishization of the black body in white supremacist culture.
} 
risk of demarcating class divisions rather than dissolving them because its deployment necessarily presumes the possession of a specific set of dispositions, typically acquired by agents capable of mobility across a range of fields only because of the capital they are able to utilize. 


\section{REFERENCES}

Abbott, A. (2007), 'Against Narrative: A Preface to Lyrical Sociology', Sociological Theory, 25:1, March, pp. 67-99.

Barnes, N. and Daley, P. (1995). Interview in Mixmag. Available at:

http://www.techno.de/mixmag/interviews/Leftfield1.html. Accessed 13 March 2009.

Bourdieu, P. (1977), Outline of a Theory of Practice, Cambridge: Cambridge University Press.

Bourdieu, P. (1984), Distinction: A Social Critique of the Judgement of Taste, London: Routledge.

Bourdieu, P. (1988), 'Intérêt et désintéressement', Cahiers de recherché, 7. I'Université de Lyon.

Bourdieu, P. (1991) Language and Symbolic Power, Cambridge: Polity.

Bourdieu, P. (1993a), Sociology in Question, trans. R. Nice, London: Sage.

Bourdieu, P. (1993b), 'Principles of a sociology of cultural works', in S. Kemal \& I. Gaskell (eds), Explanation and value in the arts, Cambridge: Cambridge University Press, pp.173.189.

Bourdieu, P. ([1992]1996), The Rules of Art, trans. S. Emmanuel, Cambridge: Polity.

Bourdieu, P. ([1996]1998a), On Television and Journalism, trans. P. Parkhurst Ferguson, London: Pluto Press.

Bourdieu, P. ([1998b]2001), Masculine Domination, Cambridge: Polity.

Bracewell, M. (2005), 'Her dark materials', The Guardian, 24 September, http://www.theguardian.com/music/2005/sep/24/popandrock.siouxsieandthebanshees. Accessed 25 September 2005.

Branch, A. (2012), 'All the young dudes: educational capital, masculinity and the uses of popular music', Popular Music, 31, pp. 25-44.

Charlesworth, S. (2000), A Phenomenology of Working Class Experience, Cambridge: Cambridge University Press.

Chris (2006), Interview responses transcript, 12 April.

Colegrave, S. and Sullivan, C. (2001), Punk. A Life Apart, London: Cassell.

Crossley, N. (2008) 'Pretty Connected: The Social Network of the Early UK Punk Movement', Theory Culture Society, 25: 89.

Deleuze, G. and Guattari, F. ([1984]2003), Anti-Oedipus: capitalism and schizophrenia, London: Continuum.

Deleuze, G. and Guttari, F. (1987), A Thousand Plateaus, Minneapolis: University of Minneapolis Press.

Ellis, J. (2013), Interview responses transcript, 8 November.

Felix, B. and Wolting, F. (2011), There is No Authority But Yourself,

http://www.youtube.com/watch?v=5LQ1CvwF7BQ. Accessed 12 November 2013.

Fowler, B. (1999), 'Pierre Bourdieu's sociological theory of culture', Variant, pp. 2: 8.

Gorman, P. (2001), In Their Own Write: Adventures in the Music Press, London: Sanctuary.

Grenfell, M. and Hardy, C. (2007), Pierre Bourdieu and the Visual Arts, Oxford: Berg.

Hawes, S. (1999), 'I was there: putting punk on television', in A. Blake (ed), Living Through Pop, London: Routledge, pp. 51-62.

Hebdige, D. (1979), Subculture: The Meaning of Style, London: Routledge.

Home, S. (1988), The assault on culture: utopian currents from lettrism to class war, London: Aporia Press and Unpopular Books, http://www.stewarthomesociety.org/ass/punk.htm. Accessed 1 March 2011.

hooks, b. (1992), 'Eating the Other: Desire and Resistance', in Black Looks: Race and Representation, Boston, MA: South End Press, pp.21-39.

Jonathan (2012), Interview responses transcript, 30 June.

Jordan (1978), Punk: the early years, http://www.youtube.com/watch?v=yIVAhH_uJHI). Accessed 15 June 2013. 
Kiszely, P. (2013), 'From place to space to scene: The Roxy Room and the emergence of Manchester's alternative pop culture identity', Punk and Post Punk, 2: 1, pp. 27-42.

Medhurst, A. (2000), 'If Anywhere: Class Identifications and Cultural Studies Academics', in S. Munt (ed), Cultural Studies and the Working Class, London: Cassell.

Myles, J. F. (2004), 'From Doxa to Experience: Issues in Bourdieu's Adoption of Husserlian Phenomenology', Theory, Culture, Society, 21, pp. 91-107.

Pountain, D. and Robins, D. (2000), Cool Rules: Anatomy of an Attitude, London: Reaktion Books.

Savage, J. (1991), England's Dreaming, London: Faber and Faber.

Savage, J. (2010), 'How punk bridged the class divide', The Independent, 10 April,

http://www.independent.co.uk/voices/commentators/jon-savage-how-punk-bridged-the-class-divide-1940753.html. Accessed 10 April 2010.

Schubert, J. Daniel (1999), 'Anti-Habitus: Schizophrenia and Symbolic Violence', in M. Grenfell and M. Kelly (eds), Pierre Bourdieu: Language, Culture and Education, Berne: Peter Lang, pp. 97-107.

Simon (2012), Interview responses transcript, 8 November.

Stolper, P. and Wilson, A. (2004) No Future: Sex, Seditionaries and the Sex Pistols, London: The Hospital.

Strongman, P. (2007), Pretty Vacant: A History of Punk, London: Orion.

Tim (2012), Interview responses transcript, 12 December.

Toynbee, P. (2008), 'The education boom has proved a curse for the poor', The Guardian, 5 July, http://www.guardian.co.uk/commentisfree/2008/jul/05/education.communities. Accessed 5 July 2008.

Unnamed punk (1977), Brass Tacks, http://www.youtube.com/watch?v=0652W7lfGvE. Accessed 15 June 2013.

Williams, R. (1977), Marxism and Literature, Oxford: Oxford University Press.

York, P. (1980), Style Wars, London: Sidgwick and Jackson.

DISCOGRAPHY

\section{Crass}

'White Punks on Hope' (from Stations of the Crass, Crass Records, 1979)

\section{FILMOGRAPHY/BROADCASTS}

Brass Tacks (BBC, 1978)

Punk: the early years (Rock Biz Pix/Martin Barker, 1978)

So It Goes (Granada, 1976)

There is no authority but yourself (Felix and Wolting, 2011)

Young Soul Rebels (British Film Institute, Channel Four Films, Iberoamericana Films Producción, Kinowelt Filmproduktion, La Sept, Sankofa Film \& Video, 1991) 
Contributor details

Andrew Branch is a Senior Lecturer in the School of Arts and Digital Industries at the University of East London, where he leads the undergraduate degree programme in Media and Communication. His current research focus is on exploring how the middle classes use social space and extract legitimated value from it. In this respect he is indebted to the legacy of Pierre Bourdieu's sociology. His most recent publications have focused on the links between the accumulation of education capital and the consumption of popular music cultures.

Contact: School of Arts and Digital Industries, University of East London, London E16 2RD.

E-mail: a.r.branch@uel.ac.uk 
